\title{
Study Title: Economics of Mazri Making as Source of Livelihood in Nomadic Lifestyle of Balochistan, Pakistan
}

\author{
Jumo Khan Bajkani ${ }^{1}$, Muhammad Afzal ${ }^{2}$, Nadeem Sadiq ${ }^{3}$, Khalil Ahmed ${ }^{4}$, \\ Ahmed Aziz Kurd ${ }^{5}$ \\ The authors are respectively the ${ }^{1}$ Scientific Officer, ${ }^{2}$ Director, SSRI, PARC, Sariab Quetta, and ${ }^{3-5}$ Senior \\ Scientific Officer, Arid Zone Research Centre, Quetta and. ${ }^{4}$ Lecturer in Balochistan Agriculture College Quetta
}

\begin{abstract}
The present study was conducted to chalk out socioeconomic characteristic, average per unit cost of production and average net return earned by the mazri producers. Mazri is a dwarf palm grows naturally in the dry tropical regions of Pakistan. Mates, ropes, banns, ornamental products, different commodities for mosques, baskets, brooms, trays, hand fans, grain bins, cordage, cupboards and decoration pieces etc. are prepared from the foliage of this plant. Balochistan is the biggest producer of Mazri in Pakistan with an average annual production of 27,265 tonnes. About 65,000 people are directly are indirectly involved in the processing of mazri leaves, among which 78\% of them are women. The involvement of women was quite active in mazri manufacturing. Most of the collection and harvesting task was performed by women. The results showed that Rs 118/- is the daily labor charges of a women working on mat making, which is far below than working anywhere else. There is no regular market of mazri, therefore the community is not availing its deserving amount of their produce.
\end{abstract}

Key Words: Mazri (dwarf palm), foliage, net return and cost of production, Balochistan

\section{Introduction}

Mazri is the local name for dwarf palm (Nannorrhops ritchiana) and mazri, a small palm, is traditionally used for making various household and other utility articles, but is also very rich in fibres. It is a gregarious, tufted, and shrubby palm, growing naturally in dry tropical regions of Pakistan. Fibers of mazri are widely used for preparation of mates, ropes, banns, ornamental products, different commodities for mosques, baskets, brooms, trays, hand fans, grain bins, cordage, cupboards and decoration pieces etc. Mazri palm is mostly found on either side of Suleiman range with the height ranging from 600-1100 $\mathrm{m}$ in sandy soil depressions [1],.Jandia (Kalpani, District Mardan), Swat, Totakan, Anbar, Kohat, Bannu in NWFP, Qasoor, Gujrat, Kot Addu in Punjab, Khuzdar, Loralai, Harnai, Musa Khail etc. in Balochistan are the famous areas of Pakistan for their various decorating and fascinating mazri commodities.

Mazri is found in the wild in patches, while it is also cultivated in some areas of the country. About 65,000 people are directly are indirectly involved in the processing of mazri leaves, among which $78 \%$ of them are women [2], The women are doing most of the job starting from harvesting to finished product. Men and women with the help of sickle harvest the mazri foliage from the growing areas. Both fresh and dried leaves are used for product making. One leaf yield about 30 to 40 pieces and $5 \mathrm{~kg}$ of leaves produce about $4 \mathrm{~kg}$ of products with waste of $20 \%$ [3]. Average annual production of raw mazri leaves in the country is 37,315 tonnes in 1991 92 [4] and [5]). Balochistan is the biggest producer of mazri in Pakistan with an average annual production of 27,265 tonnes. It has been estimated that on an average a mazri worker can process more than 0.5 tones of raw mazri leaves per year [3]. Mazri leaves are distributed in various parts of the country through railways and trucks. About 3400 tons of mazri was produced in 1999-00 [6]. Mazri palm's production was reduced to 70\% in 1999-00 compared to 1991-92. But according to [7], the production of Mazri increased to 95\% as compared to that in 1999-00 i.e. 394,559 tons. The price of the mazri raw material (leaves) used in product preparation is Rs. 300-350 and 400-500 per $50 \mathrm{~kg}$. in Khuzdar and Harnai districts of Balochistan, respectively. Average sale price of mazri leaves in the Kohat district is Rs. 100 per $40 \mathrm{~kg}$ [8] and Kalpani (Mardan) its price was Rs.200-220 per $50 \mathrm{~kg}$ [2]. There was a total export of mazri126 million rupees in Middle East countries, etc. during 1991 from various products of mazri prepared by the rural people. There is more potential of exports than the Rs. 126 millions, if various products are properly marketed and supply is maintained through sustainable harvest [3], Sources: EPB, 2001, ASP, 2001, Ziaul, 2001.).

A segment of poor people from Balochistan are involved in this profession. Keeping in view the importance of the mazri products as a source of income for poor community, the present study was designed to assess the socioeconomic environment and mazri production system followed by the mazri producers, to estimate the average per unit cost of production incurred by mazri producers, and to chalk out the channels 
involved in the production, marketing and product preparation of mazri and to compute average net return earned by the mazri producers.

\section{Methodology}

In order to achieve the study objectives, primary and secondary sources of information were used. The secondary data was collected from various sources such as libraries, Internet, NGOs etc. For primary information 50 mazri manufacturers were interviewed in Quetta district of Balochistan. Random sampling technique was used for the selection of respondents. Various steps involved in the manufacturing of mazri were analyzed. The economic analysis of the study was carried out. A team of agricultural economists from SSRI, Quetta conducted the survey in the month of September 2011. SPSS software was used for data analysis.

\subsection{Socioeconomic Characteristics of Mazri Manufacturers}

\section{Results And Discussion}

Socioeconomic information of mazri product producers revealed that an average age of respondents was found 40 years ranging from 25 to 60 years and $100 \%$ were found illiterate. Due to their mobility round the year, they cannot get their children enrolled in schools, which is one of the reasons that almost all of them were found illiterate. All professional/traditional people live in huts made of mazri in the suburb of the cities like nomads, without proper facilities of basic necessities of life. Joint family system was predominant among the sample respondents. It was revealed during the survey that 32 to 40 percent respondents were found much experienced in their field having an experience of less or more than 30 years. They narrated that their families are working in this profession since their forefathers and making mazri products as a customary work. The people move their dwelling round the year keeping in view season and market opportunities. In summer, they come to Quetta from the other cities of Balochistan, such as Lehri (22\%), Jacobabad (36\%), Nasirabad (2\%), Dera Allah Yar (28\%) and Sibi (12\%). It was found common in almost all the nomadic families that they migrate in groups and it was found identical in this migrant group. Ninety percent of the farmers reported that they move in groups, which has certain advantages. Sharing the hiring cost of a truck for more than one family is economical and feels safe while traveling in groups. Some advancement in transportation mode has been recorded. Camels were used to be the source of migration in past, which was replaced by tractors trucks, buses etc. It is an indicator of their well being and change in life style. Most of the mazri farmers belong to "Jat" and some farmers were "Pashtoon" tribe found in the study area.

The involvement of women was quite active in mazri manufacturing within the community. Mostly prepared of mazri products task was performed by women. They were not only involved in home activities but were also found involved in supplementing household income for their families. Women belonging to lowincome families make ropes, fans, baskets and mats and sell them to the traders.

\subsection{Economic condition and level of income from the mazri business}

The economic condition of mazri product maker peoples is lowering day by day. The source of income was found as primary source of income for livelihood, related with mazri business. The level of income from mazri products is decreasing day by day. The number of dependent persons per income is 8-10. Their monthly average income was ranging from Rs. 8000 to 10000 . Our result of related with mazri business people dependent persons and monthly average income comprises with results of [2]. They studied challenges faced to mazri palm: A case study of Jhandey, district Mardan" and found mazri product makers dependent persons and monthly average income almost similar in Jhandey areas.

\subsection{Production of mazri}

The production of mazri palm varies according to the favorability and suitability of climate, soil, and rainfall. The production of the foliage changes from season to season each year. The mazri palm production reduced to 70\% in 1999-00 compared to 1991-92 [3], [4] and [5]). But according to [7], the production of mazri increased to $95 \%$ as compared to that in 1999-00 i.e. 394,559 tons. The domestication of different plants is increasing due to lesser availability of products extracted (explain) from the wild and some of the restrictions by government departments like "Mazri Control Act, 1953". In Balochistan, the mazri can be found in most of the hot climatic hilly areas. However Khuzdar, Barkhan, Musakhail, Loralai and Harnai are the areas where the plant is found in abundance. Mazri is a wild plant, which is not grown by the farmers like other agricultural crops. In past its foliage was harvested freely without paying any amount for it, but now it is not free of cost for the collectors, they have to pay for it in the Khuzdar district while Harnai district people was harvested free of cost.. Survey results revealed that mazri was mainly collected from Khuzdar and Harnai districts, However 12\% of respondents who were collecting mazri leaves from Harnai district and $18 \%, 66 \%$ and $4 \%$ in Gaslati, Wadh Khuzdar and Quetta districts, respectively. Quetta is not a mazri producing area while the foliage is purchased 
by the respondents in small quantity for manufacturing from the whole sale dealers. The whole sellers purchase the mazri foliage exported from other mazri growing districts.

\subsection{Harvesting}

The mazri respondents go for harvesting in groups of three to seven men and spend eight to ten days in the field to satisfy their demand of mazri foliage. There is no specific mazri harvesting date, but depends on the needs of people and magnitude of market value, but the mazri farmers normally harvest the foliage in the months of April to August. The plant of mazri is evergreen and can be harvested anytime of the year. Many professional mazri product makers reported that they stay in the Quetta maximum till five months, but a few respondents also reported four to six months stay in the Quetta. The Mazri harvesting and its enterprise are in transition stage. They carry the harvested foliage on camels to metallic road and load on trucks for further transportation. Because mazri plants are wildly grown in the hilly areas and there is no pave road to the fields of mazri. Due to these reason camels are mostly suitable for the transportation of raw mazri from the hills. The nearby market distances are also covered by camels by carrying their finish mats or other mazri products. But the far markets and distances are covered by relying on modern transportation network, as the extension of village roads to the major cities have made it possible.

\subsection{Types of Product Prepared and main buyers of the product}

Various types of product are prepared by the respondents i.e. mats, ropes, banns, decoration products, baskets and hand fans etc. But of all mat making is commonly practiced which is being operated hundred of years back. In ancient times, the nomads have developed their skill to convert mazri leaves into mats. These mats were initially used for tents. Later on this material was applied in constructing houses. Gradually this mate making became commercialized and a group of people adopted this profession as source of income. Mat making is a hard profession where one sits hours to work getting a reduced amount of reward. Some families are involved in this business since their childhood. Mat making is the sole responsibility of their female members and men can help hands to prepare other mazri products such as hand fans, sweeps, baskets, etc. The survey results revealed that a woman spend on at least six to eight hours daily for mat making despite of other household routine work such as cooking, washing clothes, cleaning etc. Men are responsible to provide the raw material and market the final products. Although mazri is almost free natural resource for earning income by applying skill into finish farm. Since then, no research work has been carried out to know the raw material source, its labor charges and return. Different sizes of mats were observed during the survey normal, medium and large. The size of $6 \times 12$ feet was considered the normal size 10x20ft medium and $15 \times 25 \mathrm{ft}$ large. The normal size mat was prepared in one day by a woman; medium size took 1.12 days while large size could be completed by a woman in 3.16 days. They further replied that they can make any size of mats as per demand. The four dozen of sweeps was prepared in one day by a man.

During the survey, mostly buyers of the products are local and other districts of Balochistan people as most of the products are used for tent, ceiling, side of fruit trucks cleaning and other domestic problems. Summer season is always good for this business according to one of the respondents. Further; results show that daily mat sale was 1-3, 1-5 and 1-7 large, medium and normal size, respectively in the study area in the huge season. The normally soling of products good season was June to August.

\subsection{Economic Analysis}

The economical analysis describes the methods used in analyzing economic, behavior and the application of the result obtained to solve economic problem (David, 1979

\subsubsection{Capital Investment}

Capital investment is the amount of money invested in some business. It provides the means of production like; raw material, tools and building etc. in the present study, Economics of Mazri Making as Source of Livelihood, initial investment has taken in to account (table 1). Average cost of mat making was obtained from the sample respondents and the estimated costs and earning benefits were analyzed. The respondents divided the mats into three different categories as per its sizes. The average expenditure for large mat was Rs.308; medium mat costs Rs. 154 and Rs. 67 for small size (normal) mat was calculated. This expenditure shows the mazri price that includes cost of mazri leaves, camel charges, treatment cost, rope cost and transportation cost. 
Table No.1. Average cost of mat making

\begin{tabular}{|l|c|c|c|}
\hline \multicolumn{1}{|c|}{ Size of mat } & Rs/ mat & Total mats in per season (\#) & Amount (Rs) \\
\hline Large $(15 \times 25 \mathrm{ft})$ & 308 & 61 & 18788 \\
\hline Medium $(10 \times 20 \mathrm{ft})$ & 154 & 156 & 24024 \\
\hline Small $(6 \times 12 \mathrm{ft})$ & 67 & 219 & 14673 \\
\hline Total Amount (Rs.) & & $\mathbf{5 7 4 8 5}$ \\
\hline
\end{tabular}

Source: Survey data, 2011-12

\subsubsection{Costs of mazri products and migration.}

The table below reveals a cost that is paid by the respondents regarding cost of mazri leaves, transportation, camel charges, treatment, ropes and the amount paid for migration. The average estimated cost of mazri products was Rs. 57485 and migration cost was Rs.11000. The total cost of mazri farmers incurred was Rs. 68485 in the study area table 2.

Table No.2. Cost of mazri leaves/89 bundles

\begin{tabular}{|l|c|}
\hline \multicolumn{1}{|c|}{ Component Costs } & Amount (Rs) \\
\hline Cost of mazri leaves & 21327 \\
\hline Cost of camel from field to main road & 15232 \\
\hline Cost of transportation & 18279 \\
\hline Treatment cost & 1803 \\
\hline Rope cost & 844 \\
\hline Migration cost & 11000 \\
\hline Total Amount (Rs.) & 68485 \\
\hline
\end{tabular}

Source: Survey data, 2011-12, Note: $80 \mathrm{kgs} /$ bundle weight of mazri leaves

3.6.3 The prices received by the mazri producers were analyzed and it was found that average price received for large size mat was Rs.963.75/-, medium size Rs. 514/mat and small (normal) size of Rs. $185.04 /$ mat. The margin is equal to the labor charges. If we further analyze, the expenditure spent on small mat is Rs. 67 and is sold at Rs. 198 so the price margin is Rs 118. The small mat takes a single day for completion. The result showed that Rs 118 is the daily labor charges of a women working on mat making. These daily wages are far below than working anywhere else, but still they are going on with this mat making profession. However, presently the government has notified Rs 233/- daily wage for unskilled labor whereas mazri mat making is not a job of unskilled labor table 3 .

Table No.3. Average prices received by the mazri producers

\begin{tabular}{|l|c|c|c|}
\hline \multicolumn{1}{|c|}{ Size of mat } & Rs/ mat/sweeps & Total mat/sweeps & Amount \\
\hline Large $(15 \times 25 \mathrm{ft})$ & 963.75 & 61 & 58789 \\
\hline Medium (10x20 ft) & 514 & 156 & 80184 \\
\hline Small $(6 \times 12 \mathrm{ft})$ & 185.04 & 219 & 40524 \\
\hline Sweeps made by wastage leaves & 4 & 960 & 3840 \\
\hline Total Amount (Rs.) & \multicolumn{18337}{c|}{} \\
\hline
\end{tabular}

Source: Survey data, 2011-12

\subsubsection{Costs, Revenues and Returns of mazri product}

The gross value of output was composed of the value of mazri product estimated at farm gate price and the imputed value of the wastage leaves. The expenses incurred on mazri foliage and other costs were estimated in terms of imputed and purchased costs. Net income was estimated by deducting total cost from the gross value of output. It was found that the sample mazri producers had produced mazri product of average gross value amounting Rs. 183337/five months. The average mazri leaves, migration and other costs were estimated as Rs. 21327, Rs. 11000 and Rs.36158, respectively, making total cost as Rs. 68485.

The overall net income per mazri producers was computed as Rs. 114852/season, during the five months. The returns to per rupee investment and returns to per rupee spent on mazri leaves costs were estimated as almost $167.70 \%$ and $759.65 \%$, respectively. The further result shows that the revenue per day (rupees) was Rs.1222 (table 4). The percentage shares of cost on different groups of mazri leaves operations shows that mazri leaves and transportation costs constitute the highest share 57.83 percentage followed by a decreasing order of groups of mazri leaves practices as camel, migration, treatment and rope. 
Table No.4. Cost, revenue and return of mazri products in the study area of Balochistan.

(Per season)

\begin{tabular}{|l|c|}
\hline Component Costs & Amount (Rs) \\
\hline Cost of mazri leaves & $21327(31.14 \%)$ \\
\hline Cost of transportation & $18279(26.69 \%)$ \\
\hline Cost of camel from field to main road & $15232(22.24 \%)$ \\
\hline Treatment cost & $1803(2.64 \%)$ \\
\hline Rope cost & $844(1.23 \%)$ \\
\hline Migration cost & $11000(16.06 \%)$ \\
\hline Total cost (Rs.) & 68485 \\
\hline Gross revenue & 183337 \\
\hline Net-income/season & 114852 \\
\hline Net-income against mazri leaves costs (Rs./season) & 162010 \\
\hline Returns/Rs investment (\%) & 167.70 \\
\hline Returns/Rs of variable cost (\%) & 759.65 \\
\hline Stay period of duration (days) & 150 \\
\hline Revenue per day (rupees) & 1222 \\
\hline Benefit Cost Ratio & $1: 2.6$ \\
\hline
\end{tabular}

Source: Survey data, 2011-12

\section{Conclusion:}

In Pakistan, especially Balochistan has the potential for mazri and its products and can be increased manifold if major constraints are removed. The mazri working groups need to have some alternative sources for better livelihood. They have taken over this profession through inheritance from their forefathers. The people are hard working and they know the only skill of preparing mazri products. Mazri is an important plant and can play a vital role in the socioeconomic conditions of poor people of the rural areas. Many poor people of Balochistan are involved in this profession. It was reported by the farmers that several other products are made despite than mat from the mazri plant leaves, such as baskets, hand fans, sweeps, ropes, decoration item etc. Its leaves are used for the making of huts, shelters and roof construction. The plant parts are used as fuel wood. Dry leaves of mazri (peesh) are highly inflammable which are used for quick fire burning.

Mazri farmers were totally uneducated, because they migrate on traditional routes round the year. They come to Quetta from the other cities of the province like Lehri, Nasirabad (Teepul), Dera Allah Yar (Jhatpat), Harnai and Sibi. Mazri farmers reported that during the time of harvesting they face many problems such as mazri cutting and living in the mazri growing areas which is mostly in the hilly regions and there is no facility. The mazri framers go for cutting of mazri foliage in groups and they live 8-10 days in the mazri growing areas. Majority of the mazri farmers store mazri in the open fields which takes 4-10 days for drying up and further treatment. Women are responsible for mat making and men can help hands to prepare other mazri products such as hand fans, sweeps, baskets, etc. Marketing is very important for mazri products and they are not satisfied from the market prices. It has been reported that some mazri farmers have transformed their profession to agriculture farming/harvesting in their native places. The economic analysis of mazri products has been carried out based on primary data collected from the Quetta. The main problems in mazri products was identified are, self-cutting, loading/un-loading, high prices of mazri leaves, high price of transportation, fluctuating and lower prices, availability of good market for products and proper research on market development for mazri products. and poor financial problems.

\section{Recommendations:}

On the basis of study findings following recommendation are suggested for the improvement of this negated business of poor people.

- To set up an information and database.

- To arrange seminar for the betterment of this industry with the involvement of mazri community.

- Government/ NGOs should arrange better marketing facilities for mazri products within and out of country in order to maximize the income of the product makers.

- PARC with the involvement of provincial research institute should take initiatives for the plantation of mazri as a field crop, in order to save the natural vegetation and to lessen down the problem faced by the mazri manufacturers.

- In this modern age of technology, mazri farmers were using traditional methods. It may be due to illiteracy and unawareness; there for extension services may be made more effective for mazri farmers.

- Proper advertisement and exhibition for the promotion of products as well as local people should be intercede.

- There is need to promote the products both at national and international level, which will ultimately increase the income of the people and conservation of Mazri palm. 
- Training on sustainable production should be imparted to the local people for improved quality of produce

- There is pressing need of credit facilities. Government should provide loan to the mazri producers without any interest for the purchase of mazri.

- Excess to schools and hospitals must be provided to the mazri producers in their premises. Mobile schools can bring their children educated if such facility is extended to mazri makers

\section{References:}

[1] Champion, H.G, K. Steth \& G.M. Khatatak 1965. Forest type of Pakistan. PFI Peshawar

[2] Latif A, S.Begum, M.Adnan, K. Hussain and M.Waseem (2005) "Challenges Faced to Mazri Palm (Nannorhops ritchieana): A Case Study of Jhandey, District Mardan, Pakistan," Ethnobotanical Leaflets: Vol. 2005: Iss. 1, Article $27 . \quad$ (Available at: http://opensiuc.lib.siu.edu/ebl/vol2005/iss1/27 )

[3] Iqbal, M. 1991. Non-timber forest products: their income-generation potential for rural women in North West Frontier Province (Pakistan). International Labor Organization and Government of NWFP. Peshawar.

[4] Iqbal, M. 1993. International trade in non-wood forest products. An overview. FAO. Rome

[5] Export Promotion Bureau (EPB). 2001-02. Exporting Commodities of Pakistan. Ministry of Environment, Local Govt. and Rural Development, Islamabad.

[6] Agriculture Statistics of Pakistan, 1999. Ministry of Food and Agriculture. Govt. of Pakistan. Islamabad.

[7] Agriculture Statistics of Balochistan, 2000-01. Ministry of Agriculture and Cooperative. Govt. of Balochistan.

[8] Abbas, Q. 2002. Ethnobotanical Studies of Kurram Agency through Rural Community Participation. Ethnobotany Project, WWFPakistan, Peshawar. 